\title{
Spiders systematically trap amphibians in north-eastern Madagascar
}

\author{
Thio Fulgence ${ }^{1}$, Dominic Martin ${ }^{2}$, Holger Kreft ${ }^{2}$, Fanomezana Ratsoavina ${ }^{3}$, and Aristide \\ Andrianarimisa $^{2}$ \\ ${ }^{1}$ University of Antananarivo \\ ${ }^{2}$ Affiliation not available \\ ${ }^{3}$ Université d'Antananarivo
}

May 11, 2020

\begin{abstract}
Predation can take unexpected turns. For instance, various invertebrate species - most commonly spiders - may prey on tetrapods. Here, we report observations of spiders (Sparassidae, Olios sp.) preying on amphibians (Hyperoliidae, Heterixalus andrakata) in north-eastern Madagascar. To do so, the spiders built highly-specialized traps by weaving two leaves together. Four cases by different individuals of the same species show that spiders hide at the rear end of the trap. One case reports the feeding on a small frog caught inside the trap. Previous reports on amphibian predation by spiders describe opportunistic and indiscriminate predation behaviour by generalist ground-dwelling or aquatic spiders. The only more targeted cases concern large orb-weaver spiders building large webs that may serve as an effective trap for small vertebrates, but those only make up a small percentage of prey compared to insects. In contrast, the novel traps type reported here seems to be solely targeted at catching amphibians seeking shelter during the daytime. We thus report systematic trapping of amphibian by spiders, a newly recorded behaviour.
\end{abstract}

\section{Introduction}

Finding food is an important component of the animal behavior, encompassing on average more than $50 \%$ of their lifetime activity budget (Fennessy 2004). Predation is an important technique to acquire food (Kie 1999; Bertram 1979), and occurs between many different taxa, such as vertebrates preying on other vertebrates, for example a bird preying on a gecko (Koski and Merçon 2015; Lopes et al. 2005), snakes feeding on lizards (Raselimanana 2018) and amphibians catching amphibians (Rasolonjatovo et al. 2018), or between vertebrates and invertebrates, for example a bird eating a butterfly (Collins and Watson 1983; Pinheiro and Cintra 2017; Bowers et al. 1985; Stefanescu 2000; Olofsson et al. 2010; Su et al. 2015). However, invertebrates can also prey on vertebrates thereby turning around the "expected order". Reported cases are geographically widespread and highly diverse: for example, crabs preying on frogs (Pyke et al. 2013; Rosa et al. 2014), dragonfly larvae (Barej et al. 2009) and water scorpions eating tadpoles (von May et al. 2019), water bugs preying on fish (von May et al. 2019), praying mantis feeding on lizards (Jehle et al. 1996) and carabid beetles as well as spiders feeding on amphibians (Wizen \& Gasith, 2011; von Mayet al. , 2019).

Spiders are among those invertebrate predators which have also been reported to prey on vertebrates (Menin et al. 2005; Costa-pereira et al. 2010; Gaiarsa et al. 2012; Amaral et al. 2015; Kirchmeyer et al. 2017). Most reports have documented spiders to catch their vertebrate prey underwater (Bovo et al. 2014; Amaral et al. 2015; Folly et al. 2017; Kirchmeyer et al. 2017) or by active terrestrial hunting (Maffei et al. 2010; Kirchmeyer et al. 2017). Exceptionally large orb-weaver spiders can catch vertebrates such as bats, birds and amphibians in their web (Muscat et al. 2014; Kirchmeyer et al. 2017; Toledo 2005; Folt and Lapinski 2017; Nyffeler and 
Kno 2013). However, insect usually represent a larger proportion of spider prey than vertebrates, making the latter a welcome bycatch but not the main target (Kirchmeyer et al. 2017).

Generally, amphibians seem to be the favorite vertebrate prey of spiders (Fadel et al. 2019; Toledo 2005; Pedrozo et al. 2017), probably due to their soft skin (Duellman and Trueb 1986) but also due to their small to moderate size. In addition, amphibians are also preyed on by a variety of other animals (Koski and Merçon 2015; Ceron et al. 2017) and even carnivorous plants (Duellman and Trueb 1986; Bovo et al. 2014; Ceron et al. 2017).

Here, we report on a specialized trapping technique of a spider to catch amphibians as the main prey - a behavior that is, to the best of our knowledge, new to science. The predation occurred between a spider of the genus Olios sp. and a small amphibian (Heterixalus andrakata, Glaw and Vences, 1991, Least Concern) in north-eastern Madagascar. To our knowledge, this is also the first report of spider predation on amphibians in Madagascar.

\section{Materials and Methods}

\section{Study area}

We conducted field observations around Ambodiala (commune Farahalana, Sambava District) and Antsikory (commune Ampanefena, Vohemar District), north-eastern Madagascar (Fig. 1). The climate in this part of Madagascar is tropical-humid with an average annual temperature of $25^{\circ} \mathrm{C}$ and rainfall over $2133 \mathrm{~mm}$ data from 'Chelsa' climatologies (Karger et al. 2017). The landscape was formerly covered with humid evergreen forest (Du Puy and Moat 1996) but forests are nowadays fragmented (Vieilledent et al. 2018) and the landscape is dominated by smallholder agriculture.

\section{Incidental observations}

We made four incidental observations during ecological surveys implemented around the study area. DAM made the first incidental observation at 6:20 on $25^{\text {th }}$ October 2017 in a woody fallow in Ambodiala $\left(14^{\circ} 24^{\prime} 47^{\prime \prime}\right.$ $\mathrm{S}, 50^{\circ} 5^{\prime} 17^{\prime \prime} \mathrm{E}$ ) during a bird point count. The woody fallow is a former slash-and-burn (tavy) field on which rice was last cultivated in 2001. The shrubs and trees inside the woody fallow were around two to three meters high.

All other observations were made by TRF inside vanilla plantations during additional ecological surveys in the area. The second observation was on $20^{\text {th }}$ August 2018 at 19:40 in Antsikory (13 $55^{\circ} 35.8^{\prime \prime}$ S, 50 02'40.1”'E). The third observation with the same date was at 21:00 in the same village but in a different vanilla plantation $\left(13^{\circ} 55^{\prime} 49.0^{\prime \prime} \mathrm{S}, 50^{\circ} 02^{\prime} 26.3^{\prime \prime} \mathrm{E}\right)$. The fourth observation was on $3^{\text {rd }}$ October 2018 at 18:34 in Ambodiala $\left(14^{\circ} 24^{\prime} 28^{\prime \prime} \mathrm{S}, 50^{\circ} 5^{\prime} 8^{\prime \prime} \mathrm{E}\right)$. Vanilla plantations in the study region represent agroforestry systems characterized by vanilla vines growing on small-statured support trees, while tall trees provide shade.

\section{Specimens}

Two spider individuals were collected, euthanized and fixed in $90 \%$ ethanol. We labelled voucher specimens with field numbers THC140 (first observation) and THC293 (fourth observation). We measured the specimen THC140 on millimeter paper (Fig. 2 A) to record thorax and cephalothorax length. While we have not collected the frog specimen observed during the predation, we have collected one individual from the same locality of the same species and recorded with the field number THC144. It has been euthanized, fixed with $90 \%$, conserved in $70 \%$ alcohol and stored it at the University Center of SAVA Region (CURSA). Tissue biopsies of frogs and spider specimens are preserved in $90 \%$ alcohol and deposited at the Evolutionary Biology laboratory, Germany. We verified the frog identification based on DNA sequences of the 16S rRNA gene of the Mitochondrial DNA. We identified the spiders to genus level using available documents (Henon 2015).

\section{Results}

We found four different spider traps, from different individuals of the same species of spider, built by leaves of three tree species. In all four cases, two leaves (one of the same tree species) were woven together with a 
spider web (Fig. 2 B) and the spiders (Olios sp.) were hiding at the far end of the leaves. To weave the leaves together, the extremities of the leaves (inner and outer part) were pulled together by silk and became close to each other. The traps were open at the petiole part of the leaves, enabling prey climbing up the stem of the tree to enter. The spiders were well-hidden at the base of the trap (i.e. the tip of the leaves) and not visible from the entrance. The spiders do not seem to have a strong preference for a single trees species and the height from the ground also seems variable from those observations.

\section{First incidental observation}

During a bird point count in the morning, we saw how a spider (Olios sp., Sparassidae) caught an amphibian (Heterixalus andrakata, Hyperoliidae) on the leaves of Tambourissa sp. The spider held on the head of the amphibian with the fangs. The amphibian posterior legs were above the back of the spider while the head was down. The amphibian did not move anymore, so it seemed already killed. When we approached the scene, the spider with prey went hiding between two leaves of Tambourisa sp. We took photos (Fig. 2 C) and left the predation event. The tree leaves measure circa $26 \mathrm{~cm}$ in length and circa $9 \mathrm{~cm}$ in width at the widest point. The height of the leaves from the ground was around $120 \mathrm{~cm}$.

In the afternoon (16:15 of the same day), we came back to the same place and the spider was still at the same place (hiding between the leaves). We collected the specimen (Fig. 2 A) but could not find the frog prey anymore. Around the tree, within a $2 \mathrm{~m}$ radius, we found four other living individuals of Heterixalus andrakata. The two tree leaves were woven together by the spider using silk, i.e. the two leaves were pulled close to each other, closing roughly two thirds of the leaf edges.

\section{Second incidental observation}

We found the spider during a nocturnal amphibian and reptile survey in a vanilla plantation hiding between two tree leaves of Phyllarthron madagascariensis. The leaves were again woven together in the middle of the segmented leaves by the silk of the spider. The tree leaves measured ca. $29 \mathrm{~cm}$ in length and ca. $8.2 \mathrm{~cm}$ in maximum width. The height of the woven leaves where the spider hidden was around $180 \mathrm{~cm}$ from the ground.

\section{Third incidental observation}

The third observation resembled the second, but occurred in a different vanilla plantation within the same village, circa $300 \mathrm{~m}$ away from the second observation. The height of the woven leaves where the spider hidden was around $170 \mathrm{~cm}$ above the ground.

\section{Fourth incidental observation}

We found the spider hiding between leaves of Cedrela odorata. The leaves were again woven together by the silk of spider. The two leaves were closed at the top and open from the petiole (Fig. 2 D). The length of the leaf was around $8 \mathrm{~cm}$ and $3.5 \mathrm{~cm}$ in width. We found the woven leaves around $50 \mathrm{~cm}$ from the ground.

During the second through fourth incidental observations, we found the same spider species hiding between leaves of different tree species but we could not observe any predation events.

\section{Discussion}

Predation of vertebrates by invertebrates might be more common than typically assumed, and spiders are the most cited invertebrate group showing such behavior (Barej et al. 2009). However, previous reports of spiders preying on amphibians point to an opportunistic behavior and provide no evidence of specialization. Here, we report systematic predation of amphibians by spiders using targeted traps. The observed traps were always built using two leaves that seemed to have the sole purpose for amphibian trapping. Vertebrates may hence not be only an opportunistic, indiscriminate or accidental prey, but rather a targeted systematically exploited food source of Olios sp. spiders. The behavior was observed independently in four spider individuals at four different sites suggesting that the trapping behavior is frequently performed by Olios sp. in north-eastern Madagascar. To our knowledge, this is the first observation of targeted vertebrate trapping by spiders. 
The genus of Olios spiders is distributed globally with 246 species (Jäger 2012; Rayor 2018) and is included in the Sparassidae family, a group that is called 'huntsman spiders' (Rayor 2018). Most huntsman spiders do not build webs to capture their prey but actively stalk and run-down their prey with stealth and speed (Rayor 2018). However, some Sparassidae have been found in their own silk nest which is fastened with debris, living leaves or stems are completely surrounded by silk (Jackson 1987). Furthermore, most species in the family Sparassidae are nocturnal (Henon 2015; Rayor 2018).

The genus of Heterixalus frogs is arboreal and typically occurs in open areas such as clear-cut forest or rice fields (Blommers-Schlösser 1982; Raharivololoniaina et al. 2003). The species of H. andrakata is distributed in northern and north-eastern of Madagascar (Glaw and Vences 2007). During our ecological survey, we found $H$. andrakata to be mostly active at night, but recorded some daytime activity in agroforests. However, the species is typically hiding away during daytime between leaves.

A key factor facilitating the trapping behavior of Oliossp. may thus be that Heterixalus andrakata and possibly also other arboreal frogs try to hide from sunlight during the day in order to avoid dehydration (Rodel and Braun 1999). When temperatures rise, the frogs look for shade and cover away from the ground, which the spiders provide in form of their leaf trap. Additionally, the frogs might favor the seemingly protected traps in an attempt to hide from other predators such as birds that scan the vegetation for prey. The trap thus seems to be a necessity for the spider when attempting to catch frogs. Alternatively, the trap could also aim for catching prey other than frogs, such as insects. However, during our observation, no other prey was found in the traps and seeking shade seems of less importance for insects.

Interestingly, the majority of reports of amphibian predation by invertebrates stems from the Neotropics. Few predation events on Afrotropical anurans by invertebrates have been published (Barej et al. 2009). The only reports from Africa are from Tanzania and Uganda, where fishing spiders prey on tadpoles (Vonesh 2005), from South Africa where crabs predate on amphibians, and from Cameroon where wandering spiders prey on tree frogs (Barej et al. 2009). One report from Madagascar describe predation event on tree frogs (Boophis rufioculis ) by freshwater crab (Hydrothelphusa sp.) (Rosa et al. 2014).

Our observation is, to our knowledge, the first report of spider predation on vertebrates from Madagascar. Whether this geographic bias concerning amphibian predation by invertebrates is indeed reflecting a difference in the frequency of such behavior or whether the bias is due to more research being conducted in the Neotropics (Meyer et al. 2015; Martin et al. 2015) remains, however, unclear.

\section{Authors' contributions}

TRF and DAM made the observations; TRF collected data and led the writing of the manuscript with input by DAM, HK, FMR and AA. All authors contributed to the manuscript and gave final approval for publication.

\section{Acknowledgements}

We would like to thank the landowners in Ambodiala and Antsikory who let us survey their lands. We also thank our field assistants Romual Randrianantenaina and Erosiniot Befidimanana for their great support during fieldwork and James Herrera for his feedback that improved the quality of the first draft of this manuscript. We also thank Miguel Vences from Evolutionary Biology laboratory for genetic identification of the frog species. This study was financially supported by the Volkswagen Stiftung within the project 'Diversity Turn in Land Use Science' (Grant number 11-76251-99-35/13 (ZN3119)) which is a collaboration between the University of Gottingen, the University of Antananarivo, Madagascar National Parks and the University of CURSA (University Center of SAVA Region). TRF was supported by the German Academic Exchange Service (DAAD) within the 'Partnerships for Supporting Biodiversity in Developing Countries' initiative (Project Nr.57449386). We collected data under the research permit $N^{\circ} 254 / 18 / \mathrm{MEEF} / \mathrm{SG} / \mathrm{DGF} / \mathrm{DSAP} / \mathrm{SCB} . \mathrm{Re}$ granted by the Ministry for Water, Ecology and Forest (MEEF), Antananarivo.

\section{Data Accessibility Statement}


Data sharing is not applicable to this article as no new data were created or analyzed in this study. Otherwise specific data depend on the need of applicants of this study are available from the corresponding author on request.

\section{References}

Amaral, L.C., P.D.S. Castanheira, and S.P. De Carvalho-e-silva. 2015. Predation on the tropical bullfrog Adenomera marmorata (Anura: Leptodactylidae) by the wandering spider Ctenus ornatus (Araneae: Ctenidae) in southeastern Brazil. Herpetol. Notes 8:329-330.

Barej, M.F., J.A.M. Wurstner, and W. Böhme. 2009. Predation on the treefrog Leptopelis brevirostris (Anura: Arthroleptidae) by a wandering spider (Araneae: Ctenidae) in Cameroon. Herpetol. Notes 2:137-139.

Bertram, B.C.R. 1979. Studying predators. 2nd No.3. (J.J.R. Grimsdell, ed.). African Wildlife Foundation, P.O. Box 48177 Nairobi, Kenya. 50 pp.

Blommers-Schlösser, R.M.A. 1982. Observations on the Malagasy frog Heterixalus Laurent, 1944 (Hyperoliidae). Beaufortia 32:1-11.

Bovo, R.P., E.G. De Oliveira, and L.N. Bandeira. 2014. Predation on two Dendropsophus species (Anura : Hylidae) by a pisaurid spider in the Atlantic forest, southeastern Brazil. Herpetol. Notes 7:329-331.

Bowers, M.D., I.L. Brown, and D. Wheye. 1985. Bird Predation as a Selective Agent in a Butterfly Population. Evolution (N. Y). 39:93-103.

Ceron, K., V.L. Ferreira, W.M. Tomas, and D.J. Santana. 2017. Battle of giants : Predation on giant tadpole of Pseudis platensis (Anura: Hylidae) by a giant water bug (Hemiptera: Belostomatidae). Herpetol. Notes 10:263-265.

Collins, C.T., and A. Watson. 1983. Field Observations of Bird Predation on Neotropical Moths. Biotropica 15:53. DOI: https://doi.org/10.2307/2387999

Costa-pereira, R., F.I. Martins, E.A. Sczesny-moraes, A. Brescovit, C. Grande, C. Grande, and C. Grande. 2010. Predation on young treefrog (Osteocephalus taurinus) by arthropods (Insecta, Mantodea and Arachnida, Araneae) in Central Brazil. Biota Neotrop. 10:469-472.

Duellman, W.E., and L. Trueb. 1986. Biology of Amphibians. 1986. 549 pp.

Fadel, R.M., R. Thaler, H. Folly, C. Galvao, M. Hoffmann, L. Alves, D.J. Santana, and S. Mangia. 2019. Predation of anurans across multiple life stages in an Amazon - Cerrado transitional zone. Herpetol. Notes 12:895-899.

Fennessy, J. 2004. Behavioural ecology. Pp. 126-159 in Ecology of desert-dwelling giraffe Giraffa camelopardalis angolensis in northwestern Namibia. Sydney,Australia.

Folly, H., L.F. De Arruda, V.F. Gomes, M.O. Neves, and R.N. Feio. 2017. Predation on Ololygon carnevallii (Caramaschi and Kisteumacher, 1989) (Anura, Hylidae) by Phoneutria nigriventer (Keyserling, 1891) (Aranae, Ctenidae). Herpetol. Notes 10:365-367.

Folt, B., and W. Lapinski. 2017. New observations of frog and lizard predation by wandering and orb-weaver spiders in Costa Rica. Phyllomedusa 16:269-277. DOI: https://doi.org/10.11606/issn.2316-9079.vl6i2p269277

Gaiarsa, M.P., L. Rodrigues, V. De Alencar, C.J. Dias, and M. Martins. 2012. Predator or prey ? Predatory interactions between the frog Cycloramphus boraceiensis and the spider Trechaleoides biocellata in the Atlantic Forest of Southeastern Brazil. Herpetol. Notes 5:67-68.

Glaw, F., and M. Vences. 2007. Ny Toro-hay momba ny Amphibia sy ny Reptilia an’i Madagasikara. 529. Henon, N. 2015. Inventaire des araignees de la foret d'Ambodiriana et de ses alentours-Madagascar. 83. 
Jackson, R.R. 1987. The biology of Olios spp., huntsman spiders (Araneae, Sparassidae) from Queensland and Sri Lanka: predatory behaviour and cohabitation with social spiders. Bull.Br.arachnol.Soc 7:133-136.

Jager, P. 2012. New species of the spider genus Olios Walckenaer, 1837 (Araneae: Sparassidae: Sparassinae) from Laos. Zootaxa 68:61-68. DOI: https://doi.org/10.11646/zootaxa.3228.1.3

Jehle, R., A. Franz, M. Kapfer, H. Schramm, and H.G. Tunner. 1996. Lizards as prey of arthropods : Praying Mantis Mantis religiosa (LINNAEUS, 1758) feeds on juvenile Sand Lizard Lacerta agilis LINNAEUS, 1758 (Squamata: Sauria: Lacertidae). Herpetozoa 9:157-159.

Karger, D.N., O. Conrad, J. Bohner, T. Kawohl, H. Kreft, R.W. Soria-Auza, N.E. Zimmermann, H.P. Linder, and M. Kessler. 2017. Climatologies at high resolution for the earth's land surface areas. Sci. Data 4:1-20. DOI: https://doi.org/10.1038/sdata.2017.122

Kie, J.G. 1999. Optimal foraging and risk of predation: effects on behavior and social structure in ungulates. J. Mammal. 80 (4):1114-1129.

Kirchmeyer, J., L.C. Amaral, A. Magaldi, R.L. Cerqueira, and S.P. De Carvalho-e-silva. 2017. Predation on the treefrog Scinax similis (Anura: Hylidae) by the orb-weaver spider Eriophora fuliginea (Araneae: Araneidae) in southeastern Brazil. Phyllomedusa 16:113-116.

Koski, D.A., and L. Mercon. 2015. Predation on Tropidurus torquatus (Squamata: Tropiduridae) by the Guira Cuckoo Guira guira (Aves: Cuculiformes) in the state of Espirito Santo, Southeastern Brazil. Herpetol. Notes 8:35-37.

Lopes, L.E., A.M. Fernandes, and M.A. Marini. 2005. Predation on vertebrates by Neotropical passerine birds. Lundiana 6:57-66.

Maffei, F., F.K. Ubaid, and J. Jim. 2010. Predation of herps by spiders (Araneae) in the Brazilian Cerrado. Herpetol. Notes 3:167-170.

Martin, L.J., B. Blossey, and E. Ellis. 2015. Mapping where ecologists work : biases in the global distribution of terrestrial ecological observations. Ecol. Soc. Am. DOI: https://doi.org/10.1890/110154

von May, R., E. Biggi, H. Cardenas, ... D.L. Rabosky. 2019. Ecological interactions between arthropods and small vertebrates in a lowland Amazon rainforest. Amphib. Reptile Conserv. 13:65-77.

Menin, M., D.D.J. Rodrigues, and C.S. De Azevedo. 2005. Predation on amphibians by spiders (Arachnida, Araneae) in the Neotropical region. Phyllomedusa 4:39-47.

Meyer, C., H. Kreft, R. Guralnick, and W. Jetz. 2015. Global priorities for an effective information basis of biodiversity distributions. Nat. Commun. 6:1-8. DOI: https://doi.org/10.1038/ncomms9221

Muscat, E., E.L. Rotenberg, and C.A. Chagas. 2014. Predation of Scinax littoralis (Anura: Hylidae) by Eriophora fuliginea (Arenae: Araneidae) in Southeastern Brazil. Herpetol. Notes 7:169-170.

Nyffeler, M., and M. Kno. 2013. Bat Predation by Spiders. PLoS One 8. DOI: https://doi.org/10.1371/journal.pone.0058120

Olofsson, M., A. Vallin, S. Jakobsson, and C. Wiklund. 2010. Marginal eyespots on butterfly wings deflect bird attacks under low light intensities with UV wavelengths. PLoS One 5. DOI: https://doi.org/10.1371/journal.pone.0010798

Pedrozo, M., L.D.S. Almeida, M.D.T. Moroti, and D.J. Santana. 2017. Predation on Physalaemus olfersii (Anura: Leptodactylidae) by Phoneutria nigriventer (Aranae: Ctenidae) in Atlantic Forest, South-east of Brazil. Herpetol. Notes 10:369-371.

Pinheiro, C.E.G., and R. Cintra. 2017. Butterfly Predators in the Neotropics: Which Birds are Involved? J. Lepid. Soc. 71:109-114. DOI: https://doi.org/10.18473/lepi.71i2.a5 
Du Puy, D.J., and J. Moat. 1996. A refined classification of the primary a refined classification of the primary vegetation of Madagascar based on the underlying geology: using GIS to map its distribution and to assess its conservation status. Pp. 205-218 in Biogeographic de Madagascar (W.R. Lourenco, ed.). Proceedings of the International Symposium on the "Biogeography de Madagascar", Paris, September 1995.

Pyke, G.H., S.T. Ahyong, A. Fuessel, and S. Callaghan. 2013. Marine crabs eating freshwater frogs: Why are such observations so rare? Herpetol. Notes 6:195-199.

Raharivololoniaina, L., D.R. Vieites, F. Glaw, and M. Vences. 2003. Larval stages, habitat and distribution of the hyperoliid frog Heterixalus rutenbergi (Boettger, 1881). Alytes 21:59-65.

Raselimanana, A.P. 2018. Field observations of predation events in Malagasy amphibians and reptiles. Herpetol. Notes 11:659-662.

Rasolonjatovo, S.M., M.D. Scherz, A.P. Raselimanana, and M. Vences. 2018. Tadpole predation by Mantidactylus bellyi Mocquard, 1895 with brief description of the site and morphological measurements of the specimen. Herpetol. Notes 11:747-750.

Rayor, L.S. 2018. Huntsman Spider Biology: Life-History, Reproduction \& Husbandry. 1-7.

Rodel, M.-O., and U. Braun. 1999. Associations between Anurans and Ants in a West African Savanna (Anura: Microhylidae, Hyperoliidae, and Hymenoptera: Formicidae). Biotropica 31:178. DOI: https://doi.org/10.2307/2663971

Rosa, G.M., J. Noel, J. Sabino-Pinto, and F. Andreone. 2014. Predation on the treefrog Boophis rufioculis (Anura, Mantellidae) by the freshwater crab Hydrothelphusa sp. (Decapoda, Potamonautidae) in Madagascar. Crustaceana 87:890-894. DOI: https://doi.org/10.1163/15685403-00003331

Stefanescu, C. 2000. Bird predation on cryptic larvae and pupae of a swallowtail butterfly. Butlleti del Grup Catala d'Anellament 17:39-49.

Su, S., M. Lim, and K. Kunte. 2015. Prey from the eyes of predators: Color discriminability of aposematic and mimetic butterflies from an avian visual perspective. Evolution (N. Y). 69:2985-2994. DOI: https://doi.org/10.1111/evo.12800

Toledo, L.F. 2005. Predation of juvenile and adult anurans by invertebrates: Current knowledge and perspectives. Herpetol. Rev. 36:395-400.

Vieilledent, G., C. Grinand, F.A. Rakotomalala, R. Ranaivosoa, J.R. Rakotoarijaona, T.F. Allnutt, and F. Achard. 2018. Combining global tree cover loss data with historical national forest cover maps to look at six decades of deforestation and forest fragmentation in Madagascar. Biol. Conserv. 222:189-197. DOI: https://doi.org/10.1016/j.biocon.2018.04.008

Vonesh, J.R. 2005. Sequential predator effects across three life stages of the African tree frog, Hyperolius spinigularis. Oecologia 143:280-290. DOI: https://doi.org/10.1007/s00442-004-1806-x

Wizen, G., and A. Gasith. 2011. Predation of amphibians by carabid beetles of the genus Epomis found in the central coastal plain of Israel. Zookeys 100:181-191. DOI: https://doi.org/10.3897/zookeys.100.1526 

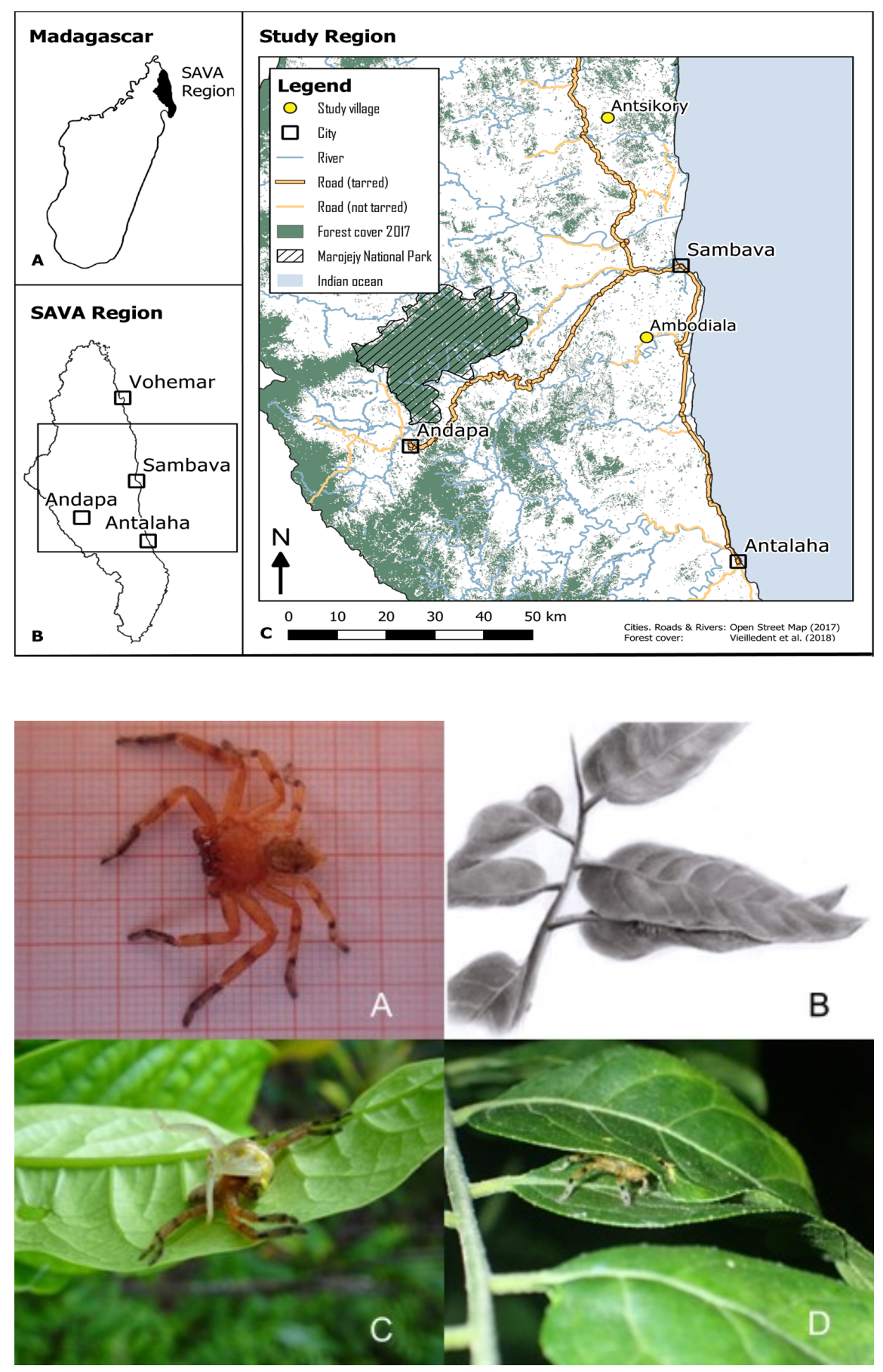